\title{
Utilization Of Colored Flowers as An Alternative Learning Media of Acid Base Indicator On Basic Chemistry Course With Green Chemistry Insight
}

\author{
Mitarlis \\ Department of Chemistry \\ Universitas Negeri Surabaya \\ Jl. Ketintang Surabaya Indonesia \\ mitarlis@unesa.ac.id
}

\author{
Utiya Azizah \\ Department of Chemistry \\ Universitas Negeri Surabaya \\ Jl. Ketintang Surabaya Indonesia \\ utiyaazizah@unesa.ac.id
}

\author{
Bertha Yonata \\ Department of Chemistry \\ Universitas Negeri Surabaya \\ Jl. Ketintang Surabaya Indonesia \\ berthayonata@unesa.ac.id
}

\begin{abstract}
Using of natural product like colored plants or flowers as a medium for learning chemistry can realize of green chemistry principles by applying one or several of its principles. One of the principles of green chemistry that can be raised in basic chemistry learning is "use renewable feedstock". Chemistry as a science that based on experiments is inseparable from laboratory activities that require chemicals in the implementation of its activities. Actually chemistry is very close to the student daily lives. Therefore learning is designed by utilizing natural product around us for chemistry learning. Indonesia has biodiversity that potentially to be used in all fields, including in learning. One way is to utilize various types of colored plants or flowers that can found around students' lives in the territory of Indonesia as an indicator of acid and base. The research method is followed the steps of research and development. Development of learning tools with green chemistry insight for basic chemistry courses. One of them is learning media as a component of learning tools by utilizing plant or colored flowers as chemical materials in practicum which can realize green chemistry insight in learning. Based on the results and data analysis from this study, several colored flowers were identified their pH stretch and potentially to be used as natural acid base indicator in chemistry learning. Some of the colored flowers are; Hibiscus rosa sinensis, Bougainvillea glabra, and Ipomea ficifolia. It is recommended to develop this study for other plants or flowers. By utilizing natural materials as a medium for chemistry learning, it can realize green chemistry based learning by applying one of its principles
\end{abstract}

Keywords-green chemistry, natural acid and base indicator, chemistry learning

\section{INTRODUCTION}

Chemistry learning has been held in class, and also inseparable from practical activities in the laboratory or field. Chemistry is known as a science based on experiments. Experiments in the laboratory require chemicals, which are usually obtained by buying from distributors or the chemical industry. Even though chemistry is actually very close to our daily life. It is also as written in the introduction chapter of a basic chemistry book that our world is a chemical world, every day we swim in a sea of chemistry [1]. The statement can be interpreted that chemistry can never be separated from human life. Humans also have never been separated from chemistry. Chemistry is present in everyday life, industry, and various aspects of life such as agriculture, health, food and drinks. Therefore, it is also important that chemistry is presented in learning, especially chemistry learning. The design of chemistry learning can be held by utilizing natural products around the students. Indonesia is famous for being prosperous and rich in natural beauty. Various kinds of colored flowers can grow well in the territory of Indonesia as a tropic climate. Indonesian soil can grow a variety of plants and plants both intentionally and that grow wild without being planted and cared for by human hands.

In previous research, there were some study about using of colored flower like Hibiscus plant as medicine [2], antioxidant activity scavenging [3], antioxidant activity and photochemical analysis [4, 5], antimicrobial compounds [6] and antibacterial activity [7]. It also used in material industries, like synthesize of gold and silver nanoparticles [8]; as a modulated the expressions of marker genes involved in diabetic stress signaling pathway [9]. According to the previous research there were not found yet the use of colored flower as medium in learning chemistry.

The potential natural product around us can be utilized as sources of learning and media for chemistry learning. For example, utilizing several colored flowers that are exists around us can be used as natural acid and base indicator to support chemistry learning, especially in basic chemistry course. Utilizing renewable natural resources can realize the principle of green chemistry No.7 in the twelve principles of green chemistry which is 'use of renewable feedstock'.[10].

The Basic Chemistry course as a branch of Natural Sciences and their practicum activities, has a great opportunity to implement environmental education in order to realize Green Education by implementing several green chemistry principles. In the implementation of the learning process in the classroom as well as in the laboratory so far it has actually integrated character values, especially those with a green chemistry insight, which sometimes we are not aware. Green Chemistry is a philosophy or concept that drives the design of a product or process that reduces or eliminates the use and production of hazardous substances.[11]. 
Green chemistry has 12 principles that can be adapted to be adopted as an insight in human attitudes and actions in efforts to save the environment. The action to save the environment can be done early by implementing in the field of education at all levels that can be realized through green education.[12].

Based on the previous study [12] the results of the identification of the green chemistry principles as an insight for the analysis of the science characters value in order to realize of green education were obtained several green chemistry principles, among others; preventing or reducing the formation of waste, the use of renewable materials, the principle of atomic economics, energy efficiency, designing materials that can be degraded, real-time analysis to prevent pollution, and creating safe conditions and preventing accidents. These findings are of great benefit if they can be implemented in learning. One of the principles of green chemistry that can be implemented in chemistry learning like in this study is "the use of renewable feedstocks". Utilization of renewable natural product in this article is the use of colored flowers as natural indicators of acid and base. In this article the results of the study are presented to answer several issues, namely how to use colored flowers as an indicator of acid and base in learning chemistry with a green chemistry insight; how does the stretch of $\mathrm{pH}$ of natural acid and base indicators from the extract of some colored flowers?

\section{METHOD}

The research method in overall by using the research and development (R\&D) design was adapted from [13]. The stages of development consist of 6 stages: a preliminary study through literature and document review, learning materials development, expert review, empirical study, and the final product. In principle, this method consists of three stages, namely: the preliminary study which is supported by reference study, the stage of development studies, and the evaluation stage by experts.

Data collection techniques at the preliminary study stage were carried out need assessment through literature studies related to chemistry learning materials, studies on green chemistry, and the development of learning media with green chemistry insight by utilizing renewable feedstock, in this case there were several colored flowers namely; hibiscus flowers (Hibiscus rosa sinensis), Bougenville (Bougainville glabra), and the wild trumpet purple flowers (Ipomea ficifolia). Limited trial were conducted to test the feasibility of using colored flowers as natural indicators of acid and base in laboratory tests were also carried out by determining the $\mathrm{pH}$ stretch. The data analysis technique was carried out in a quantitative and qualitative descriptive manner based on the compatibility with the data obtained.

\section{RESULT AND DISCUSSION}

The involvement of the green chemistry principles as an insight that will be given to students in Basic Chemistry lectures is also identified both for learning in class and in the laboratory. Implementation and integration of the principles of green chemistry in laboratory activity needs to be tested first. This is very important so that the application of the green chemistry principles can provide benefits in accordance with its objectives, but does not reduce the meaning and essence of practicum activities undertaken.
Especially in acid-base practicum activities with the use of natural indicators to realize the principle of green chemistry No. 7.

\section{A. Preliminary study}

The results of the preliminary study indicate that the basic chemistry practicum instructions used especially in acid-base material have not used many natural product indicators. Therefore it is necessary to develop indicators of acid-base sourced from nature that can be used for practicum. The results of the analysis of the characteristics of students who can use the results of development in this study are students who are programming basic chemistry courses from various majors. Chemistry practicum activities for students majoring in chemistry have become commonplace. The development of natural acid base indicator practicum material is expected to accommodate the interests of students from the biology or physics department who are not of interest but are doing chemical practicum. Based on the preliminary study also obtained data from observations that the material used for practicum in this research is colored flowers that are easily obtained in an environment close to students, even in the school or campus environment.

\section{B. Laboratory Test of Colored Flower as Natural Indicator}

Practicum with the title indicator of natural acid base was carried out with the aim to determine the change in color of some plant extracts (colored flowers) that exist in nature that have the potential as indicators of acid base. Obviously this title can fulfill the principle of green chemistry number 7 , namely the use of renewable materials. The trial begins with the preparation of tools and materials used for natural acid base indicator practicum. In this case the natural materials used are hibiscus flowers (Hibiscus rosa sinensis), Bougenville flowers (Bougainville glabra), and wild purple trumpet flowers that some call it the name 'Morning Glory (Ipomea ficifolia) which can be found in the surrounding environment.

Hibiscus rosa-sinensis is a shrub ornamental plant and belongs to the Malvaceae tribe originating from East Asia. In addition, this flower is also commonly found in various parts of the world that have tropical or subtropical climates. This plant has a large flower shape, has several color variants. In Indonesia, there are many that are red and have no odor. Flowers from various cultivars (characteristic or peculiarity) and hybrids (crossing) can produce a variety of flower variants, in the form of a single flower (a layer of crowns) or double flowers (layered crowns) which have white to yellow, orange to dark red or red guava. In Sumatra and Malaysia, hibiscus flowers are commonly referred to as botanicals. Meanwhile, the Javanese used to call it flower. Hibiscus is widely used as an ornamental plant because of its beautiful flowers. This flower is used to polish shoes in India and as a flower offering. In China, red flowers are used as food coloring agents. In Indonesia, leaves and flowers are used in various traditional treatments. Dried hibiscus is also drunk as tea.[14]. This flower is generally red in its original variety and generally has no aroma. Several colors are available in single, double or multi-color colors including white, yellow, orange, red, pink, purple, etc. [15]. The hibiscus flower used in this study was of the red Hibiscus rosa sinensis species as shown in Figure 1. 


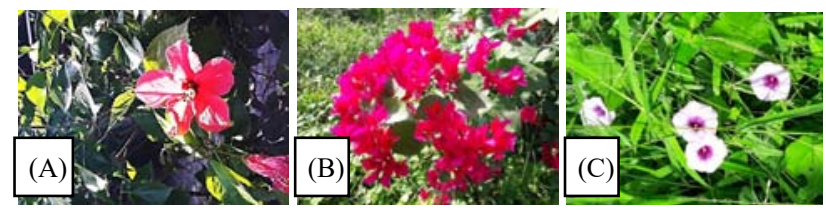

Figure 1. Several colored flowers that were used in this study for making natural acid and base indicators: Hibiscus rosa sinensis (A), Bougainvillea glabra (B), Ipomea ficifolia (C)

Bougainvillea commonly known as paper flower. In this study we use the species of Bougainvillea glabra shown in Figure 1 (B) which for the next referred to as B. glabra and also known as Lesser Bougainvillea or Bougainvillea. Paper Flower is a native plant of Brazil but now it cultivates all tropical and subtropical countries as an ornamental plant. Grows 1 - 12 m (4 - 40 feet). Multi-colored small flowers usually appear in groups surrounded by colorful papery bracts, so-called paper flowers. They have various colored flowers such as magenta, purple, red, orange, pink, yellow, white, violet, and others. They tend to flower throughout the year in the equator. Elsewhere, they are seasonal, with a bloom cycle usually of four to six weeks. But the original flower is stored in the papery bracts from summer to autumn. There are single and double flower forms. The logs tend to bend and thin stems have sharp spines and dark green leaves. Bougainvillea can be easily planted as a fence, arch or tree in the ground and in pots. Bougainville is available in a variety of species, ideal for bonsai [16]. Bougainvillea glabra can grow from root cuttings and branch cuttings. Cuttings can multiply plants easily. Cuttings must be planted in the shade until the roots are formed. The shoots, which are several inches long, can be planted in sandy soil with heat and moisture at the bottom. Bougainvillea is best in dry conditions. They need full sunlight, warm weather and welldrained soil for good flowering.[17].

The Paper Flower Plant or Bougenville (especially B. glabra) is a popular ornamental plant. The shape is a small tree that is difficult to grow upright. Its beauty comes from the sheath of brightly colored flowers and attracts attention because it grows with lush. This flower sheath is often considered a part of the flower, although the true flower is a small flower that is protected by a colorful sheath. Therefore, the bougainvillea plant is a very popular ornamental plant because of its color beauty and how to care for it easily.[18].

Wild purple trumpet flower is one of the beautiful flowers that without the touch of a human hand can flourish and is very charming. Flowers as shown in Figure 1C are also called 'Morning Glory'. In Indonesia, purple and pink flowers whose stems spread and spread known as the type of Ipomea ficifolia. Although growing in the wild, but plants that have beautiful flowers are often used by the community to decorate the yard and terrace of the house. This flower spreads to form like a beautiful carpet.[19]. Ipomoea is the largest genus in the flowering family of Convolvulaceae, with more than 500 species. This plant is a large and diverse group with several common names including morning glory, water convolvulus or kale, sweet potato, bindweed, moonflower, etc.[20]. The genus of Ipomea can grow in all tropical and subtropical regions of the world, and consists of annual and perennial herbaceous plants, lianas, shrubs and small trees; most species are wrapped around climbing plants.[21]. However, many also grow at the surface of the soil such as the species Ipomea ficifolia as shown in Figure 1 (C).

Based on the characteristic of several colored flower as depicted on Figure 1, indicate that the colored flower are potentially to use as natural acid and base indicator. So it need test in laboratory to know the color changing in several stretch of $\mathrm{pH}$.

\section{The Results for $p H$ Strectch Determination}

The use of colored flowers as natural acid and base indicator is used by extracting the color from the flower crown. Extraction can be done by using water or alcohol solvents. The result of extraction process is then dropped into comparative solution that has been prepared and was determined their $\mathrm{pH}$. The results of color changes of extract in the solution with various $\mathrm{pH}$ determine the stretch of $\mathrm{pH}$ of each colored flowers are presented in Table 1.

TABLE I. DATA OF COLOR CHANGE SOLUTIONS WITH VARIOUS PH WHEN ADDED A COLORED FLOWERS EXTRACT

\begin{tabular}{|c|c|c|c|}
\hline No. & $\begin{array}{l}\text { Material/ } \\
\text { Treatment }\end{array}$ & Figure & $\begin{array}{l}\text { Color changing and } \\
\text { stretch } \mathrm{pH}\end{array}$ \\
\hline 1a & $\begin{array}{l}\text { Flower: } \\
\text { Hibiscus } \\
\text { rosa } \\
\text { sinensis } \\
\text { Solvent: } \\
\text { Alcohol }\end{array}$ & $\begin{array}{l}\text { Color changing of } \\
\text { extract of Hibiscus } \\
\text { rosa sinensis flower } \\
\text { in } \mathrm{pH} 1-14\end{array}$ & $\begin{array}{l}\text { pH 1-2 = light red } \\
\text { pH 3-8 = pink } \\
\text { pH 9-10= soft purple } \\
\text { pH } 11=\text { light green } \\
\text { pH } 12=\text { purple green e } \\
\text { pH } 13=\text { dark green } \\
\text { pH } 14=\text { dark yellow }\end{array}$ \\
\hline $1 \mathrm{~b}$ & $\begin{array}{l}\text { Flower: } \\
\text { Hibiscus } \\
\text { rosa } \\
\text { sinensis } \\
\text { Solvent: } \\
\text { Water }\end{array}$ & $\begin{array}{l}\text { Color changing of } \\
\text { extract of Hibiscus } \\
\text { rosa sinensis flower } \\
\text { in } \mathrm{pH} 1-14\end{array}$ & $\begin{array}{l}\text { pH 1= light red } \\
\text { pH 2-4 = soft purple } \\
\text { pH 5-8 = dark purple } \\
\text { pH 9-10 = light green } \\
\text { pH 11-12 = dark green } \\
\text { pH } 13=\text { yellow green } \\
\text { pH } 14=\text { yellow }\end{array}$ \\
\hline 2 & $\begin{array}{l}\text { Flower: } \\
\text { Bougainnvi } \\
\text { llea glabra } \\
\text { (Red) } \\
\text { Solvent: } \\
\text { Water }\end{array}$ & $\begin{array}{l}\text { Color changing of } \\
\text { extract of } \\
\text { Bougainvillea } \\
\text { glabra flower in } \\
\text { pH } 0-14\end{array}$ & $\begin{array}{l}\text { pH } 0=\text { purple } \\
\text { pH 1-3= soft purple } \\
\text { pH 4-11= pink } \\
\text { pH } 12=\text { dark brown } \\
\text { pH } 13=\text { light brown } \\
\text { pH } 14=\text { yellow }\end{array}$ \\
\hline 3 & $\begin{array}{l}\text { Flower: } \\
\text { Ipomea } \\
\text { ficifolia } \\
\text { Solvent: } \\
\text { Water }\end{array}$ & $\begin{array}{l}\text { Color changing of } \\
\text { extract of Ipomea } \\
\text { ficifolia flower in } \\
\text { pH } 0-14\end{array}$ & $\begin{array}{l}\text { pH } 0-3=\text { light pink } \\
\text { pH } 4-7=\text { red brown } \\
\text { pH } 8-10=\text { light brown } \\
\text { pH } 11=\text { dark brown } \\
\text { pH } 12-13=\text { green } \\
\text { pH } 14=\text { yellow }\end{array}$ \\
\hline
\end{tabular}

Based on the results of trials in the laboratory about natural indicators in Table 1 shows that green chemistry principle No. 7 namely the use of renewable materials, can 
also apply other green chemistry principles. With the selection of the use of water solvents rather than alcohol in the extraction process can be more economical and safer, can apply the principle of green chemistry No. 5. Table 1 shows that hibiscus flower extract can be used as an indicator of natural acid base by showing a color change on a stretch of $\mathrm{pH} 0,1,2-4$, showing different colors in an acidic condition. The change in color of hibiscus flower extracts from $\mathrm{pH} 5$ to 8 shows the same color change trend, namely dark purple, but with different intensity. In this area there is a transition from a slightly acidic, neutral and slightly alkaline condition. Starting from $\mathrm{pH} 9$ shows a significant color change that is to green, with light green color degradation at $\mathrm{pH} 9-10$, and dark green at $\mathrm{pH} 11-12$ in an alkaline condition. At $\mathrm{pH} 13$ it turns yellowish green and dark yellow at $\mathrm{pH} 14$ in an alkaline.

Hibiscus flower extracts that use both alcohol and water solvents have a $\mathrm{pH}$ stretch in three regions namely; first in an acidic atmosphere at $\mathrm{pH} 0$ dark red, $\mathrm{pH} 1$ bright red, and $\mathrm{pH}$ 2-4 light purple; the second at $\mathrm{pH}$ between 5-8 gives almost the same dark purple color, and the third region in the alkaline atmosphere with $\mathrm{pH}$ 9-10 light green, $\mathrm{pH}$ 11$12=$ dark green / brown, $\mathrm{pH} 13$ yellowish green, and $\mathrm{pH} 14$ gives a dark yellow color. Bougenville flower extract with water solvent has a $\mathrm{pH}$ route in two regions; first in an acidic to alkaline atmosphere give a purple color trend $\mathrm{pH}=0$, light purple $\mathrm{pH}=1-3$, pink, $\mathrm{pH}=4-11$. The second area in a strong alkaline atmosphere gives a brown to yellow trend, pH 12 = gives a dark brown color, $\mathrm{pH}=13$ gives a light brown color, $\mathrm{pH}=14$ gives a yellow color. Purple wild flower extract (Ipomea ficifolia) with water solvent has a $\mathrm{pH}$ route in three regions namely; first in an acidic atmosphere at $\mathrm{pH}$ 0-3 pink, $\mathrm{pH}$ 4-7 brownish red. The second area gives a brown color trend, $\mathrm{pH} 8-10$ light brown, $\mathrm{pH} 11$ dark brown. The third area gives a trend of green to yellow, $\mathrm{pH}$ 12-13 in green and $\mathrm{pH} 14$ in yellow.

Analysis of learning development research data by utilizing natural colored flowers and determining the $\mathrm{pH}$ range of natural indicators of colored flower extracts can be concluded that; Utilization of renewable natural materials can meet one of the principles of green chemistry, namely the 7th principle of "use renewable feedstock". Colored flowers obtained include hibiscus flowers (Hibiscus rosasinensis), Bougenville (Bougainville glabra), and Ipomea ficifolia which have the potential to be used as indicators of acid base in chemistry learning. With the use of natural materials, some colored flower extracts as chemical learning media, can realize green chemistry learning by applying one of its principles, namely the 7th principle, used renewable feedstock. Based on data changes in color of several colored flowers namely hibiscus flowers (Hibiscus rosa-sinensis), Bougenville (Bougainville glabra), and Ipomea ficifolia extracts from $\mathrm{pH} 0$ to 14 shows a very significant color difference between stertch in acidic, slightly acidic-neutraland slightly alkaline transition regions, and in alkaline conditions. This shows that several colored flowers have the potential to be used as natural acid base indicator in chemistry learning. The uses of renewable natural feedstock can meet the principles of green chemistry, especially principle No. 7.

\section{CONCLUSION}

Analysis of learning development research data by utilizing natural flower flowers and determining the $\mathrm{pH}$ range of natural indicators of colored flower extracts can be concluded that; Utilization of renewable natural materials can meet one of the principles of green chemistry, namely the 7th principle of "use renewable feedstock". Colored flowers obtained include hibiscus flowers (Hibiscus rosasinensis), Bougenville/Bougenvillea glabra, and Ipomea ficifolia which have the potential to be used as indicators of acid base in chemistry learning. Hibiscus flower extract has a $\mathrm{pH}$ stretch in three areas namely; first in an acidic atmosphere at $\mathrm{pH} 0$ dark red, $\mathrm{pH} 1$ bright red, and $\mathrm{pH} 2-4$ light purple; the second at $\mathrm{pH}$ between $5-8$ gives almost the same dark purple color, and the third region in the alkaline atmosphere with $\mathrm{pH}$ 9-10 light green, $\mathrm{pH}$ 11-12 = dark green / brown, $\mathrm{pH} 13$ yellowish green, and $\mathrm{pH} 14$ gives a dark yellow color. With the use of natural materials as a medium for learning chemistry, green chemistry learning can realize learning by applying one of its principles.

Hibiscus flower extract has a pH stretch in three areas namely; first in an acidic atmosphere at $\mathrm{pH} 0$ dark red, $\mathrm{pH} 1$ bright red, and $\mathrm{pH} 2-4$ light purple; the second at $\mathrm{pH}$ between 5-8 gives almost the same dark purple color, and the third region in the alkaline atmosphere with $\mathrm{pH} 9-10$ light green, $\mathrm{pH}$ 11-12 = dark green / brown, $\mathrm{pH} 13$ yellowish green, and $\mathrm{pH} 14$ gives a dark yellow color. With the use of natural materials as a medium for learning chemistry, green chemistry learning can realize learning by applying one of its principles. Hibiscus flower extracts that use both alcohol and water solvents have a $\mathrm{pH}$ route in three regions namely; first in an acidic atmosphere at $\mathrm{pH} 0$ dark red, $\mathrm{pH} 1$ bright red, and $\mathrm{pH}$ 2-4 light purple; the second at $\mathrm{pH}$ between 5-8 gives almost the same dark purple color, and the third region in the alkaline atmosphere with $\mathrm{pH}$ 9-10 light green, $\mathrm{pH}$ 1112 = dark green / brown, $\mathrm{pH} 13$ yellowish green, and $\mathrm{pH} 14$ gives a dark yellow color.

Bougenville flower extract with water solvent has a $\mathrm{pH}$ route in two regions; first in an acidic to alkaline atmosphere give a purple color trend $\mathrm{pH}=0$, light purple $\mathrm{pH}$ $=1-3$, pink, $\mathrm{pH}=4-11$. The second area in a strong alkaline atmosphere gives a brown to yellow trend, $\mathrm{pH} 12=$ gives a dark brown color, $\mathrm{pH}=13$ gives a light brown color, $\mathrm{pH}=$ 14 gives a yellow color.

Purple wild flower extract (Ipomea ficifolia) with water solvent has a $\mathrm{pH}$ route in three regions namely; first in an acidic atmosphere at $\mathrm{pH}$ 0-3 pink, $\mathrm{pH}$ 4-7 brownish red. The second area gives a brown color trend, $\mathrm{pH}$ 8-10 light brown, $\mathrm{pH} 11$ dark brown. The third area gives a trend of green to yellow, $\mathrm{pH} 12-13$ in green and $\mathrm{pH} 14$ in yellow.

\section{ACKNOWLEDGMENT}

We would like to thank to Universitas Negeri Surabaya and Ministry of Research Technology and Higher Education by DRPM. We also appreciate and thank to Staff and Students of Chemistry Department who was involved in this research. 


\section{REFERENCES}

[1] B. Sugiarto, et. al., "Kimia Umum". Jurusan Kimia FMIPA Universitas Negeri Surabaya". Surabaya: Unesa University Press. 2013, pp. 2-4.

[2] M. Kaleemullah, K. Jiyauddin, E. Thiban, S. Rasha, S. Al-Dhalli, S Budiasih, O.E. Gamal, A. Fadli, Y. Eddy., "Development and evaluation of Ketoprofen sustained release matrix tablet using Hibiscus rosa-sinensis leaves mucilage". Saudi Pharmaceutica Journal. Volume 25, Issue 5, July 2017, pp. 770-779.

[3] Abd El-Moneim Mohamed Radwan Afify, A. El-Moneim M.R.\&Hassan, H.M.M. "Free radical scavenging activity of three different flowers-Hibiscus rosa-sinensis, Quisqualis indica and Senna surattensis". Asian Pac J Trop Biomed 2016; 6(9): 771-777.

[4] Garg, D., Shaikh, A., Muley, A., Marar, T., "In-vitro antioxidant activity and phytochemical analysis in extracts of Hibiscus rosasinensis stem and leaves". Free Radicals and Antioxidants Vol.2 / Issue 3 / Jul-Sep, 2012, pp. 41-46.

[5] Sheth, F. \& Subrata D., "Evaluation of comparative antioxidant potential of four cultivars of Hibiscus rosa-sinensis L. by HPLCDPPH method". Free Rad. Antiox. Vol.2 / Issue 4 / Oct-Dec, 2012, pp. 73-78.

[6] J.E. Morvin Yabesh, S. Vijayakumar, P. Arulmozhi, P.K. Praseetha."Identification and isolation of antimicrobial compounds from the flower extract of Hibiscus rosa-sinensis L: Insilico and in vitro approaches". Microbial Pathogenesis. 2018, doi: 10.1016/j.micpath.2018.08.003.

[7] P. Ruba, \& K. Gajalakshmi, "In vitro antibacterial activity of Hibiscus rosa-sinensis flower extract against human pathogens". Asian Pacific Journal of Tropical Biomedicine. 2012, pp. 399- 403.

[8] D. Philip, "Green synthesis of gold and silver nanoparticles using Hibiscus rosasinensis". Physica E. Vol. 42. 2010, 1417-1424.

[9] Sneha S. Pillai, S. Mini, "Polyphenols rich Hibiscus rosa sinensis Linn. petals modulate diabetic stress signalling pathways in streptozotocin-induced experimental diabetic rats". Journal of Functional Foods. Vol. 20, 201 6, pp. 31-42.

[10] Anastas, P.T. \& Warner, J.C., "Green Chemistry: Theory and Practice. Oxford University Press: New York. By Permission of Oxford University Press. 1988.

[11] Manahan, S.E. 2006. "Green Chemistry and The Ten Commandements of Sustainability". Second Edition. USA: ChemChar Research Inc. Publishers. 2006, pp. 9-10.

[12] Mitarlis, Bertha Y., \& Rusly H. 2015. "Analisis Nilai Karakter Sains Berwawasan Green Chemistry pada Perkuliahan Kimia Dasar dalam Rangka Mewujudkan Green Education”. Proceeding SNKPK vol.1., 2015, ISBN: 978-602-14397-1-5 National Seminar of Chemistry and Chemiatry Education 2015. Department of Chemistry Universitas Negeri Semarang.

[13] Sjaifullah, A., "Developing Speaking Materials for The Students of Mechanical Engineering at State Polytechnic of Malang. Jurnal Linguistik Terapan, 1(1), 2011, pp. 10-18.

[14] Kembang Sepatu. https://id.wikipedia.org/wiki/Kembang_sepatu

[15] Verma, "Hibiscus rosa-sinensis L. (Malvaceae): A Multipurpose Ornamental Plant”. IJRPP |Vol.6 | Issue 1 | Jan- Mar - 2017

[16] Zane, T.L. "Bougainvillea - Bougainvillea glabra". Online: https://web.archive.org/web/ 20140309030224/ http://www.bonsaibci.com/files/Bougainvillea.pdf

[17] Bougainvillea glabra. https://en.wikipedia.org/wiki/Bougainvillea glabra

[18] Ganesha Flora Bali. "Bunga Kerta (Bougenville)". Online: http://ganesha-flora.blogspot.com/2016/07/bunga-kertas-bougenville. html.

[19] Ridwant. "Bunga Liar Berwarna Ungu". https://steemit.com/flower/ (a)ridwant/bunga-liar-berwarna-ungu-122d6e8a59021

[20] Rackham, J. Ipomea. Online: https://en.wikipedia.org/ wiki/Ipomoea

[21] Gunn, Charles R. "moonflower". Brittonia. 24 (2): 1972, pp. 150-168. doi:10.2307/2805866. JSTOR 2805866. 